NOTE

\title{
Nucleotide diversity of Japanese isolates of infectious hematopoietic necrosis virus (IHNV) based on the glycoprotein gene
}

\author{
T. Nishizawa, S. Kinoshita, W.-S. Kim, S. Higashi, M. Yoshimizu* \\ Faculty of Fisheries Sciences, Hokkaido University, Hakodate, 041-8611, Japan
}

\begin{abstract}
Infectious hematopoietic necrosis virus (IHNV), a member of the genus Novirhabdovirus, causes a highly lethal disease of salmonid fish. In the present study, G gene nucleotide sequences of 9 Japanese IHNV isolates obtained from 1971 to 1996 were analyzed to evaluate the genetic diversity and compared with IHNV isolates from North America and Europe. A radial phylogenetic tree revealed 5 major clusters including 3 genogroups (U, M and L) for North American isolates and 1 genogroup for European isolates. Five Japanese isolates from 1971 to 1982 appeared in the cluster for genogroup U, while the remaining Japanese isolates from 1980 to 1996 formed a new genogroup, JRt (Japanese rainbow trout). Maximum nucleotide diversity among the Japanese isolates was $4.5 \%$, which was greater than that within the North American isolates $(3.6 \%)$, and the degree of nucleotide diversity within Japanese isolates was increased by inclusion of the genogroup JRt isolates. It was concluded that Japanese isolates shared a common source with the genogroup U of the North American isolates and that there were large divergences between Japanese isolates before and after the 1980s.
\end{abstract}

KEY WORDS: IHNV $\cdot$ Fish rhabdovirus $\cdot$ Glycoprotein gene $\cdot$ Phylogenetic relatedness $\cdot$ Evolution

Resale or republication not permitted without written consent of the publisher

\section{INTRODUCTION}

Infectious hematopoietic necrosis (IHN) of salmon and trout is one of the most important viral diseases in aquaculture facilities. Outbreaks of IHN result in losses approaching $100 \%$ depending on the species and size of the fish, the virus strain and environmental conditions (Wolf 1988). IHNV, the aetiological agent of IHN, is currently enzootic throughout the Pacific Northwest of North America, and is thought to have been spread by the movement of fish and fish eggs to Asian and European countries where it has become established among populations of rainbow trout Oncorhynchus mykiss (Winton 1991, Bootland \& Leong 1999). IHNV has a broad host range and is capable of infecting essentially all species of salmonid fish (Wolf
1988); however, losses due to IHNV are principally observed among sockeye salmon $O$. nerka, chinook salmon $O$. tshawytscha and rainbow trout.

IHNV, a member of the genus Novirhabdovirus, has a linear single-strand, negative-sense RNA genome of approximately $11 \mathrm{k}$ nucleotides. The IHNV genome contains 6 genes in the order $3^{\prime}$-N-P-M-G-NV-L-5', encoding the nucleocapsid protein $(\mathrm{N})$, phosphoprotein $(\mathrm{P})$, matrix protein $(\mathrm{M})$, glycoprotein $(\mathrm{G})$, nonvirion protein (NV) and polymerase (L), respectively (Kurath et al. 1985, Morzunov et al. 1995, Tordo et al. 2005). Since the 1980s, phenotypic and genetic diversity among IHNV isolates from different geographical areas has been investigated (Hsu et al. 1986, Winton et al. 1988, Ristow \& Arnzen de Avila 1991, LaPatra et al. 1994, Oshima et al. 1995, Emmenegger et al. 2000, 
Troyer et al. 2000, Emmenegger \& Kurath 2002). Recently, it has been confirmed by phylogenetic analyses with the nucleotide sequences of the G and NV genes that the genetic relationship of IHNV isolates correlates with the geographic origin rather than with host species or the date of isolation (Nichol et al. 1995). Furthermore, phylogeography of 323 IHNV isolates based on partial $\mathrm{G}$ gene sequences revealed 3 major genogroups, denoted U, M and L, which generally correlated with the geographic areas in the Pacific Northwest of North America (Garver et al. 2003, Kurath et al. 2003).

IHN did not occur in Japan before 1970 although chinook salmon eggs had been regularly imported from Washington state, USA since 1967. The first detection of IHNV in Japan was in kokanee salmon Oncorhynchus nerka fry at the Mori hatchery, Hokkaido, in 1971. This facility had received sockeye salmon eggs from Alaska through the Chitose hatchery, Hokkaido. Subsequently, IHN occurred in kokanee and sockeye salmon fingerlings at several hatcheries in Hokkaido in 1972, and chum salmon O. keta at Toyama Prefecture on Honshu, the main island of Japan, in 1973. IHNV subsequently spread to salmon farms throughout Japan due to the inadvertent transportation of IHNV-contaminated fish eggs (Kimura \& Yoshimizu 1991, Yoshimizu 1996). It is believed that the original source of IHNV in Japan was introduced from Alaska via a shipment of IHNV-contaminated fish eggs (Kimura \& Yoshimizu 1991, Yoshimizu 1996), although there is little molecular genetic evidence. Significant losses of cultured fry and fingerlings due to IHN were observed in kokanee salmon, masu salmon $O$. masou and rainbow trout, but have been significantly reduced since the 1980s by disinfection of fish eggs and fish culture facilities (Yoshimizu 2003). Since the 1990s, losses of commercial size fish (>50 g in body weight) due to IHNV have re-emerged at rainbow trout farms on Honshu. It is thus considered that the pathogenicity of Japanese IHNV isolates against adult rainbow trout changed at some point during the 1980s. The objective of the present study is to analyse the epidemiology and genetic diversity of Japanese IHNV isolates from 1971 to 1996 based on G gene nucleotide sequences, and to compare these with worldwide IHNV isolates.

\section{MATERIALS AND METHODS}

Nine Japanese isolates of IHNV, ChAb76, ChYu78, KoMo71, RtNag76, RtNag82, RtNag96, RtToya80, RtTochi86 and AyTochi86, were used in this study. The first 2 letters of each isolate name indicate the host fish; i.e. Ch, Ko, Rt and Ay denote chum salmon, kokanee salmon, rainbow trout and ayu Plecoglossus altivelis, respectively. The following letters indicate the area of isolation; i.e. Ab, Yu, Mo, Nag, Toya and Tochi denote Abashiri, Yurappu, and Mori on Hokkaido, and Nagano, Toyama and Tochigi Prefectures on Honshu (Fig. 1). The numbers at the end of each isolate designation indicate the year of isolation. For example, ChAb76 denotes an isolate from chum salmon in Abashiri in 1976. These Japanese isolates of IHNV were stocked in $-80^{\circ} \mathrm{C}$ with low culture-passes (maximum 10 passes) until use for nucleotide sequence analysis. The culture-passes of virus isolates should not reflect the resultant nucleotide sequences of the target $\mathrm{G}$ gene because the isolate has been shown to be remarkably stable during 510 passes in cell culture in novirhabdoviruses (Jørgensen et al. 1995).

Virus was propagated in rainbow trout gonad (RTG2) or epithelioma papilosum cyprini (EPC) cells, which were maintained at $15^{\circ} \mathrm{C}$ with Eagle's minimum essential medium (MEM, Gibco) supplemented with 10\% fetal bovine serum, $100 \mathrm{IU} \mathrm{ml}^{-1}$ penicillin $\mathrm{G}$ and $100 \mu \mathrm{g}$ $\mathrm{ml}^{-1}$ streptomycine sulfate. Viral genome RNA was extracted from the infected cells by a guanidine thiocyanate method using an RNA extraction kit (Isogen, Nippon Gene) according to the manufacturer's instructions. The extracted viral genome was subjected to RTPCR amplification for the $G$ gene open reading frame (ORF) with primers HG(-31:-12) (5'-AGA ACG CAA CTC GCA GAG AC-3') and HG(1602:1622) (5'-GTG GGG AGG AAG TGA AGA TTG-3`), which were

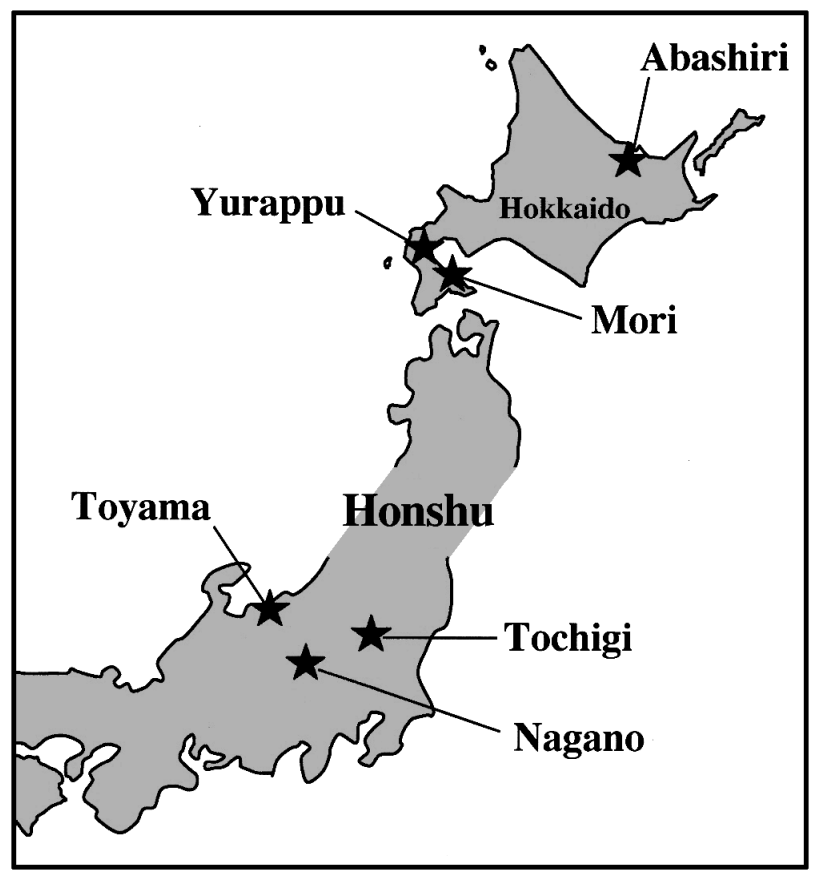

Fig. 1. Location map for sampling of IHNV isolates 
designed based on a nucleotide sequence of the WRAC strain of IHNV (accession number L40883). For reverse transcription, extracted RNAs were pre-heated at $95^{\circ} \mathrm{C}$ for $5 \mathrm{~min}$, and then incubated at $42^{\circ} \mathrm{C}$ for $30 \mathrm{~min}$ in $10 \mu \mathrm{l}$ of PCR buffer (10 mM Tris- $\mathrm{HCl}, \mathrm{pH} 8.3$ and $50 \mathrm{mM} \mathrm{KCl}$ ) containing $100 \mathrm{U}$ of $\mathrm{M}-\mathrm{MLV}$ reverse transcriptase (Takara, Japan), $1.0 \mu \mathrm{M}$ of HG(-31:-12) primer, $1 \mathrm{mM}$ of dNTP and $5 \mathrm{mM}$ of $\mathrm{MgCl}_{2}$. After incubation at $99^{\circ} \mathrm{C}$ for $10 \mathrm{~min}$, targeted DNA was amplified in $50 \mu \mathrm{l}$ of PCR buffer containing $0.2 \mu \mathrm{M}$ of the PCR primers, $1.25 \mathrm{U}$ of Taq DNA polymerase (Promega), $0.2 \mathrm{mM}$ of dNTP and $1.5 \mathrm{mM}$ of $\mathrm{MgCl}_{2}$ using a thermal cycler (Astec PC-806) programmed for 1 cycle at $72^{\circ} \mathrm{C}$ for $10 \mathrm{~min}$ and $95^{\circ} \mathrm{C}$ for $2 \mathrm{~min}$, then 30 cycles at $95^{\circ} \mathrm{C}$ for $1 \mathrm{~min}, 60^{\circ} \mathrm{C}$ for $1 \mathrm{~min}, 72^{\circ} \mathrm{C}$ for $1 \mathrm{~min}$, and finally $72^{\circ} \mathrm{C}$ for $5 \mathrm{~min}$. The amplified products were analyzed by $1.5 \%$ agarose-TAE (40 mM Tris-acetate, pH 8.0 and 1 mM EDTA) gel electrophoresis.

After being purified with a PCR purification kit (Stratagene), amplified products from viral genomes were subjected to nucleotide sequence analysis using an ABI PRISM dye terminator sequencing chemistry (Applied Biosystems) with ID4 primer (5'-CTC TGG ACA AGC TCT CCA AGG-3', Miller et al. 1998) and the PCR primers, HG(-31:-12) and HG(1602:1622), according to the manufacture's instructions. Triplicate PCR products originating from independent RT reactions were sequenced for each isolate. The resulting sequences were assembled with the software Dnasis (Hitachi) to identify and exclude duplicate sequences from the data set. Based on a single representative of each sequence, a multiple alignment of the sequences was constructed using Clustal X (Thompson et al. 1994, 1997) to infer genetic relationships among sequences with neighbor joining criteria, and a final radial tree was drawn with the software NJplot and Unrooted (Perrière \& Gouy 1996). The determined nucleotide sequences were registered with the DNA data bank of Japan (DDBJ) as accession numbers AB250927 to AB250935. Deposited nucleotide sequences of IHNV isolates in DDBJ were used for comparison purposes: RB (M16023), RB-76a (U15170), RB-76b (L40880), RB1 (U50401), LWS-87 (L40879), Carson-89 (L40872), LR-73 (L40877), SRCV (L40881), Col-80 (L40873), Col-85 (L40874), LR-80 (L40878), HO-7 (L40876), 193-11 (L40871), WRACa (L40883), WRACb (L40882), CST-82 (L40875), G4 (AF244128), StrainK (X73872), $\lambda$ ZAPII (X89213), Fs13 (AY331658), FsVi100/96 (AY331666), Fs62/95 (AY331664), Fs42/95 (AY331663), Fs30/95 (AY331662), Fs832/94 (AY331661), FsK/88 (AY331665), Fs8/99 (AY331660), Fs28 (AY331659), and 332 (AY331657) (Koener et al. 1987, Robert et al. 1988, Kim et al. 1994, Morzunov et al. 1995, Nichol et al. 1995, Schutze et al. 1995, Enzmann et al. 2005).

\section{RESULTS AND DISCUSSION}

Based on estimates from agarose gel, approximately $1.7 \mathrm{kbp}$ of PCR products corresponding to the G gene region were amplified with the primers HG(-31:-12) and $\mathrm{HG}(1602: 1622)$ from all 9 Japanese isolates of IHNV (data not shown). Sequence analysis revealed that all the PCR products contained a single ORF for the G protein gene with 1527 bases encoding a polypeptide of 508 amino acids. Comparing the nucleotide sequences, a maximum diversity of $5.6 \%$ was found among 38 isolates from Japan, North America and Europe (Table 1). This is slightly lower than the value (8.6\%) found by Kurath et al. (2003) because the former is based on the full length of the G gene whereas the latter was based on a partial G gene (303 bases).

A radial tree of phylogeny based on full-length $G$ gene nucleotide sequences revealed 5 major clusters among 38 isolates from Japan, North America and Europe (Fig. 2). Three of the 5 clusters were for genogroups U, M and L, which were previously identified by Kurath et al. (2003) for the North American isolates. These 3 genogroups generally correlated with the geographical origin of the isolates; i.e. the genogroup $U$ includes isolates from Alaska, British Columbia, Washington coastal watershed, and the Columbia River basin; the genogroup $M$ includes isolates from the Columbia River basin and Idaho; and the genogroup L includes isolates from California and the southern Oregon coast (Kurath et al. 2003). Another major cluster for European isolates was also previously identified by Enzmann et al. (2005). Five of the Japanese isolates from 1971 to 1982, ChAb76, ChYu78, KoMo71, RtNag76 and RtNag82, appeared within the cluster for the genogroup U (Fig. 2), showing that these Japanese isolates were nearly identical (within $1.8 \%$ of nucleotide diversities) to the genogroup $\mathrm{U}$ isolates (Table 1). The remaining Japanese isolates, RtNag96, RtToya80, RtTochi86, AyTochi86 and G4, formed a new cluster for a genogroup JRt (Japanese rainbow trout) (Fig. 2) although the genogroup JRt isolates seemed to share a common source with North American isolates belonging to genogroup U. The Japanese IHNV isolate was introduced in 1971 from Alaska most likely with contaminated sockeye salmon eggs (Yoshimizu 1996). Unfortunately, no Alaskan isolate of IHNV was included in the present data set, but all Alaskan isolates belong to the genogroup U (Emmenegger et al. 2000, Kurath et al. 2003). Thus, the present result could be genetic evidence to support the historical speculation of Yoshimizu (1996) on the origin of Japanese IHNV.

The maximum nucleotide diversity of the Japanese isolates was $4.5 \%$, which was $1.3 \times$ greater than that of North American isolates (3.6\%) and $2.8 \times$ greater than that of genogroup $U$ isolates $(1.6 \%)$. The degree of 


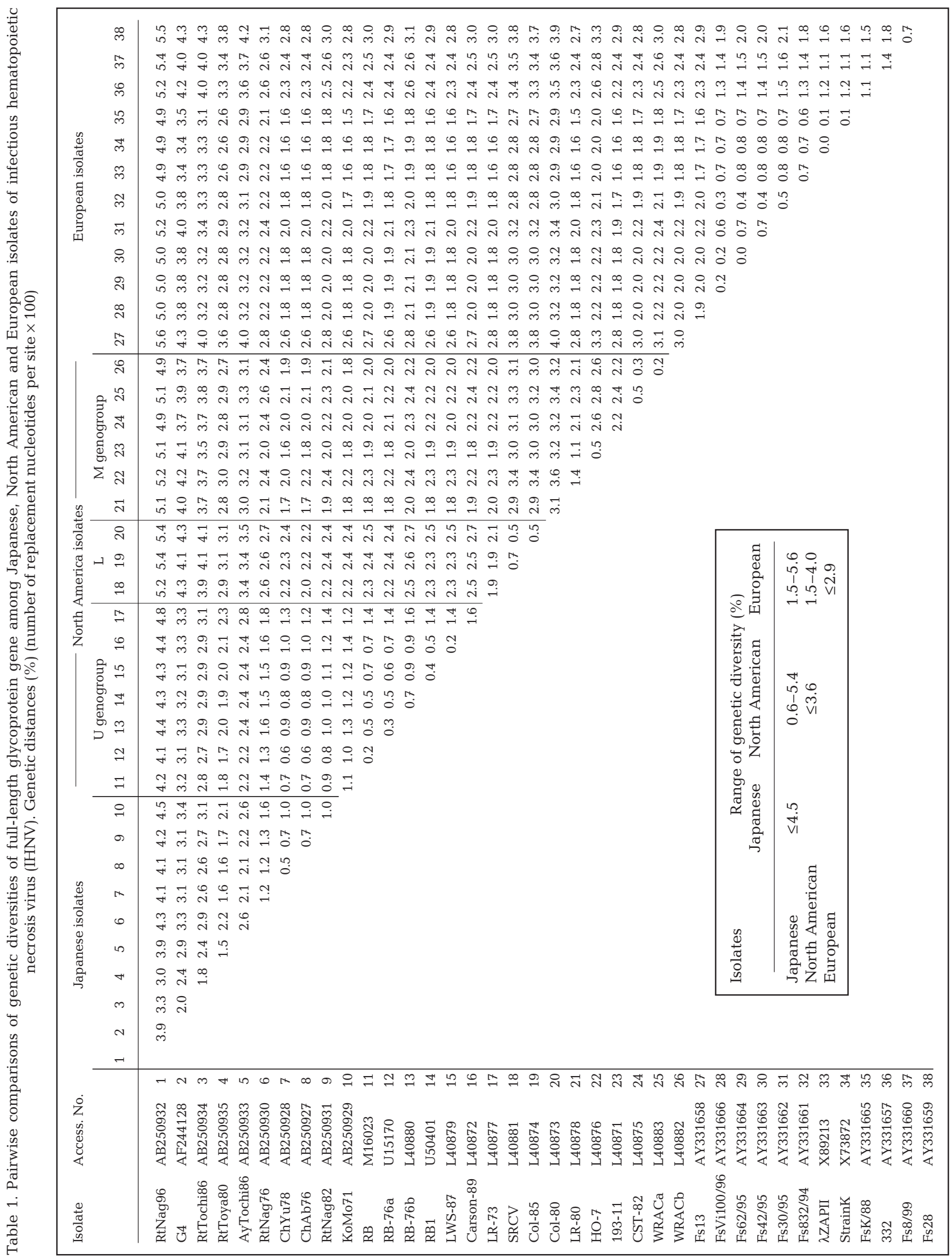




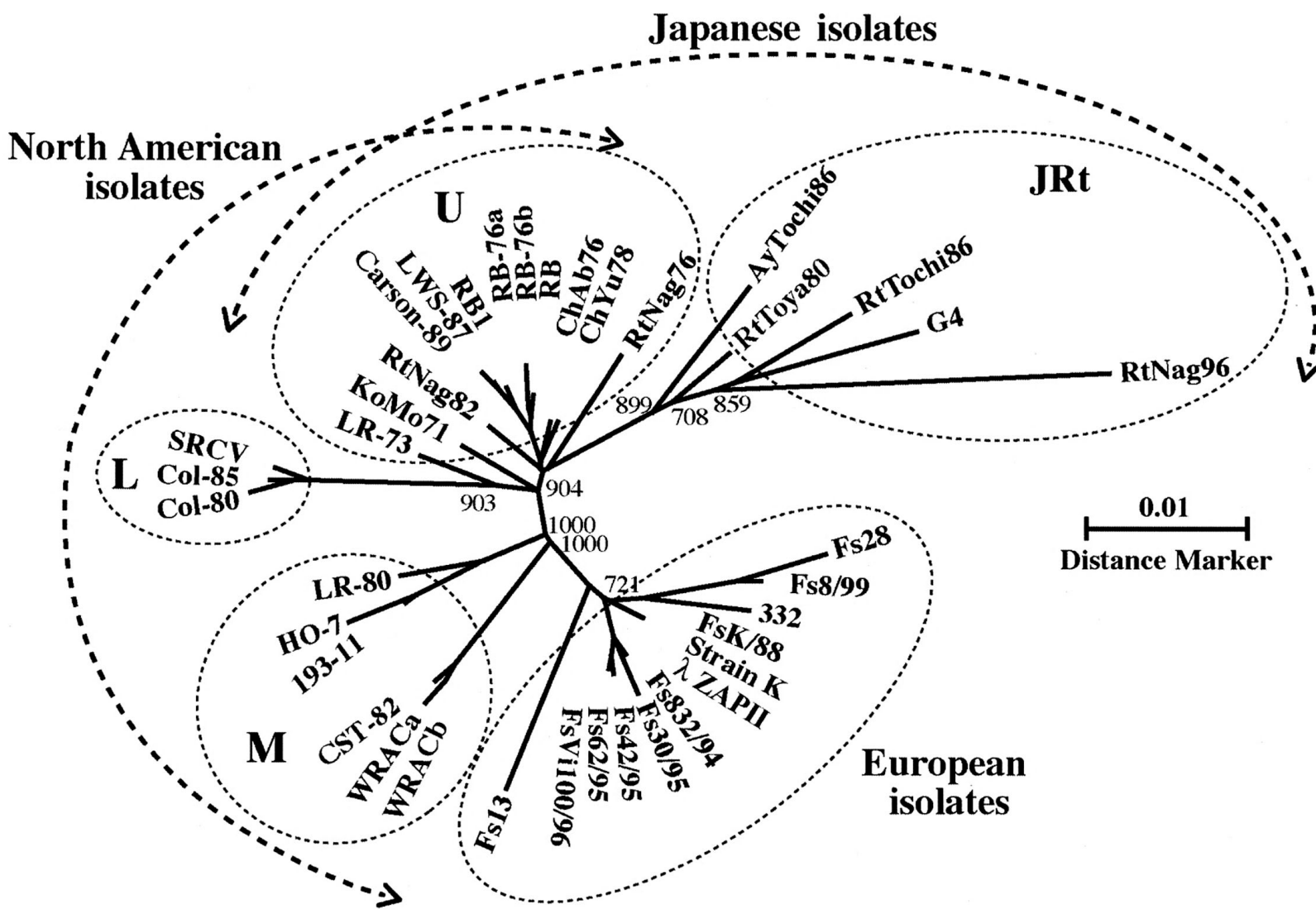

Fig. 2. Molecular phylogenetic tree showing the genetic relationships among 38 isolates of infectious hematopoietic necrosis virus based on the nucleotide sequence of the glycoprotein gene. Bootstrap values at 1000 times of construction are shown at major nodes in the tree. Distance marker refers to the expected numbers of substitutions per site

nucleotide diversity within Japanese isolates was increased by inclusion of genogroup JRt isolates from rainbow trout and ayu obtained in the 1980s and 1990s, especially RtNag96. This could suggest that RtNag96 was the result of more rapid evolution in a rainbow trout farm environment since around 1980. It was previously estimated that the rate of evolution in the G gene of IHNV isolates from farmed rainbow trout was approximately 6-fold higher than that from salmonid fish having an ocean migration phase (Troyer et al. 2000, Garver et al. 2003, Kurath et al. 2003). This may be due to viral adaptation to rainbow trout, viral infection at a higher water temperature $\left(15^{\circ} \mathrm{C}\right)$, and/or the intense production of rainbow trout in farms. These combined effects may facilitate more rapid virus evolution and diversification (Kurath et al. 2003). A similar pattern has also been observed with viral hemorrhagic septicemia virus (VHSV), where the nucleotide substitution in VHSV G gene from farmed freshwater fish was approximately $2.5 \times$ faster than that from freeliving fish in sea-water (Einer-Jensen et al. 2004). The evolution rate of the RtNag96 isolate was calculated to be approximately $1.5 \times 10^{-3}$ nucleotide substitutions per site per year, a value close to that observed in genogroup $M$ isolates from rainbow trout in North America $\left(1.2 \times 10^{-3}\right.$ nucleotide substitutions per site per year; Kurath et al. 2003). Rapid evolution among genogroup JRt isolates was also supported by the placement of isolates G4, RtTochi86 and RtToya80 in the present tree (Fig. 2); therefore, the environmental conditions for rapid evolution of IHNV could be similar between Japanese and Idaho trout farms.

Genetic evidence was presented in this study for the existence of high divergences between Japanese isolates before and after the 1980s, and our further research will investigate how this evolutionary divergence influences viral pathogenicity.

Acknowledgements. The authors gratefully acknowledge Dr. Nomura of the National Salmon Resources Center for contributing IHNV isolates from the Hokkaido area. Many thanks to Dr. Kurath of the U.S. Geological Survey, Western Fisheries Research Center for fruitful discussions and suggestions on the phylogenetic analysis. Virus isolates of Nagano Prefecture were provided by Dr. Motonishi of the Nagano Prefectural Fisheries Experimental Station. This study was partially supported by a Grant-in-Aid from the Ministry of Education, Culture, Sports, Science and Technology, and by a Grant-inAid for 21st Century COE Program from JSPS. 


\section{LITERATURE CITED}

Bootland LM, Leong JC (1999) Infectious hematopoietic necrosis virus. In: Woo PTK, Bruno DW (eds) Fish diseases and disorders, Vol 3. Viral, bacterial and fungal infections. CABI Publishing, New York, p 57-121

Einer-Jensen K, Ahrens P, Forsberg R, Lorenzen N (2004) Evolution of the fish rhabdovirus viral haemorrhagic septicaemia virus. J Gen Virol 85:1167-1179

Emmenegger EJ, Kurath G (2002) Genetic characterization of infectious hematopoietic necrosis virus of coastal salmonid stocks in Washington State. J Aquat Anim Health 14: $25-34$

Emmenegger EJ, Meyers TR, Burton TO, Kurath G (2000) Genetic diversity and epidemiology of infectious hematopoietic necrosis virus in Alaska. Dis Aquat Org 40: 163-176

Enzmann PJ, Kurath G, Fichtner D, Bergmann SM (2005) Infectious hematopoietic necrosis virus: monophyletic origin of European isolates from North American genogroup M. Dis Aquat Org 66:187-195

Garver KA, Troyer RM, Kurath G (2003) Two distinct phylogenetic clades of infectious hematopoietic necrosis virus overlap within the Columbia River basin. Dis Aquat Org 55:187-203

Hsu YL, Engelking HM, Leong JC (1986) Occurrence of different types of infectious hematopoietic necrosis virus in fish. Appl Environ Microbiol 52:1353-1361

Jørgensen PEV, Einer-Jensen $\mathrm{K}$, Higman KH, Winton JR (1995) Sequence comparison of the central region of the glycoprotein gene of neutralizable, non-neutralizable, and serially passed isolates of viral haemorrhagic septicaemia virus. Dis Aquat Org 23:77-82

Kim CH, Winton JR, Leong JC (1994) Neutralization-resistant variants of infectious hematopoietic necrosis virus have altered virulence and tissue tropism. J Virol 68:8447-8453

Kimura T, Yoshimizu M (1991) Viral diseases of fish in Japan. Annu Rev Fish Dis 1:67-82

Koener JF, Passavant CW, Kurath G, Leong J (1987) Nucleotide sequence of a cDNA clone carrying the glycoprotein gene of infectious hematopoietic necrosis virus, a fish rhabdovirus. J Virol 61:1342-1349

Kurath G, Ahern KG, Pearson GD, Leong JC (1985) Molecular cloning of the six mRNA species of infectious hematopoietic necrosis virus, a fish rhabdovirus, and gene order determination by R-loop mapping. J Virol 53:469-476

Kurath G, Garver KA, Troyer RM, Emmenegger EJ, EinerJensen K, Anderson ED (2003) Phylogeography of infectious hematopoietic necrosis virus in North America. J Gen Virol 84:803-814

LaPatra SE, Lauda KA, Jones GR (1994) Antigenic variants of infectious hematopoietic necrosis virus and implications for vaccine development. Dis Aquat Org 20:119-126

Miller TA, Rapp J, Wastlhuber U, Hoffmann RW, Enzmann PJ (1998) Rapid and sensitive reverse transcriptase-polymerase chain reaction based detection and differential diagnosis of fish pathogenic rhabdoviruses in organ samples and cultured cells. Dis Aquat Org 34:13-20

Morzunov SP, Winton JR, Nichol ST (1995) The complete genome structure and phylogenetic relationship of infec-

Editorial responsibility: Jo-Ann Leong,

Kaneohe, Hawaii, USA tious hematopoietic necrosis virus. Virus Res 38:175-192

Nichol ST, Rowe JE, Winton JR (1995) Molecular epizootiology and evolution of the glycoprotein and non-virion protein genes of infectious hematopoietic necrosis virus, a fish rhabdovirus. Virus Res 38:159-173

Oshima KH, Arakawa CK, Higman KH, Landolt ML, Nichol ST, Winton JR (1995) The genetic diversity and epizootiology of infectious hematopoietic necrosis virus. Virus Res 35:123-141

Perrière G, Gouy M (1996) WWW-Query: an on-line retrieval system for biological sequence banks. Biochimie 78: 364-369

Ristow SS, Arnzen de Avila J (1991) Monoclonal antibodies to the glycoprotein and nucleoprotein of infectious hematopoietic necrosis virus (IHNV) reveal differences among isolates of the virus by fluorescence, neutralization and electrophoresis. Dis Aquat Org 11:105-115

Robert D, Gilmore JR, Leong JC (1988) The nucleocapsid gene of infectious hematopoietic necrosis virus, a fish rhabdovirus. Virology 167:644-648

Schutze H, Enzmann PJ, Kuchling R, Mundt E, Niemann H, Mettenleiter TC (1995) Complete genomic sequence of the fish rhabdovirus infectious haematopoietic necrosis virus. J Gen Virol 76:2519-2527

Tordo N, Benmansour A, Calisher C, Dietzgen RG and 6 others (2005) Family Rhabdoviridae. In: Fauquet CM, Mayo MA, Maniloff J, Desselberger U, Ball LA (eds) Virus taxonomy. Eighth report of the international committee on taxonomy of viruses. Elsevier, Academic Press, p 623-644

Troyer RM, LaPatra SE, Kurath G (2000) Genetic analyses reveal unusually high diversity of infectious haematopoietic necrosis virus in rainbow trout aquaculture. J Gen Virol 81:2823-2832

Thompson JD, Higgins DG, Gibson TJ (1994) Clustal W: improving the sensitivity of progressive multiple sequence alignment through sequence weighting, position-specific gap penalties and weight matrix choice. Nucleic Acids Res 22:4673-4680

Thompson JD, Gibson TJ, Plewniak F, Jeanmougin F, Higgins DG (1997) The Clustal X windows interface: flexible strategies for multiple sequence alignment aided by quality analysis tools. Nucleic Acids Res 25:4876-4882

Winton JR (1991) Recent advances in detection and control of infectious hematopoietic necrosis virus in aquaculture. Annu Rev Fish Dis 1:83-93

Winton JR, Arakawa CK, Lannan CN, Fryer JL (1988) Neutralizing monoclonal antibodies recognize antigenic variants among isolates of infectious hematopoietic necrosis virus. Dis Aquat Org 4:199-204

Wolf K (1988) Infectious hematopoietic necrosis virus. In: Wolf (ed) Fish viruses and fish viral diseases. Cornell University Press, Ithaca, NY, p 83-114

Yoshimizu M (1996) Disease problems of salmonid fish in Japan caused by international trade. Rev Sci Tech Off Int Epiz 15:533-549

Yoshimizu M (2003) Control strategy for viral diseases of salmonids and flounder. In: Lee CS, O'Bryen PJ (eds) Biosecurity in aquaculture production systems: exclusion of pathogens and other undesirables. World Aquaculture Society, Baton Rouge, LA, USA, p 35-41

Submitted: July 20, 2005; Accepted: May 16, 2006

Proofs received from author(s): August 5, 2006 